\title{
European Union information: an investigation of need amongst public library users in three Scottish authorities
}

\author{
Rita Marcella and Graeme Baxter \\ The School of Information and Media \\ The Robert Gordon University
}

The School of Information and Media at the Robert Gordon University in Aberdeen recently completed a British Library funded project which investigated the provision of European Union information in public libraries in the United Kingdom, and in particular the implementation of the Public Information Relay (PIR) - a European Commission sponsored initiative designed to bring EU information closer to the British public through the existing public library network. At the outset of the project, membership of the Public Information Relay stood at 154 of the then 167 United Kingdom public library authorities. The full results of the study have been published as a British Library Research and Innovation Report $^{\mathrm{i}}$, and an abridged version has appeared in the journal Library Management ${ }^{\mathrm{ii}}$. This paper, however, focuses on one particular element of the project: a questionnaire-based survey, conducted by the research team, which investigated the European information needs of public library users. This survey aimed to elicit information from members of the public on their past use of public libraries and other sources for obtaining European information; on the types of European information that they might wish to obtain; and on the reasons why they might want to use such information. The questionnaire (a copy of which can be found at Appendix 1) was tested on members of the project team's families and on non-academic members of the School of Information and Media's staff. It was felt important, in design of the questionnaire, that respondents should be able to complete it quickly and that the questions should be unambiguous. The questionnaire consisted in the main of closed questions but allowed respondents to express freely their prior experience of requiring European information. However, in predicting future need, a list of possible topics was presented in order to ensure that respondents considered a range of possibilities. Prior to the project the only research into European information need had been the annual Gallup surveys, commissioned by the Representation of the European Commission in the United Kingdom (see references): these surveys were considered in designing the present study.

For the exercise the School of Information and Media enlisted the help of three public library services - Aberdeen, Glasgow and Moray - who each distributed 150 questionnaires to library 
users. Aberdeen gave out 50 from its Central Library's Reference Department, 50 from its Central Library's Business and Technical Department, and 50 from its busiest branch library; Glasgow gave out 50 from the Mitchell Library's Social Sciences Department, 50 from the Mitchell's Business Department, and 50 from one of its busiest branch libraries; while Moray gave out 100 from the Reference Department of its main library in Elgin (it has no separate Business Department), and 50 from one of its busier branch libraries ${ }^{1}$. As Aberdeen had not yet made the Public Information Relay service publicly available, the questionnaires distributed there did not include Question 3 ("Are you aware that the library is part of a network of public libraries providing European information?"). The libraries were asked if systematic sampling might be used, whereby every 10th user approaching the issue/enquiry desk would be given a questionnaire. However, it is appreciated that the library staff involved in the exercise will have had many other pressures on their time and that such a systematic approach may not always have been possible. The libraries were also asked if they could request that the users complete and return the questionnaires at the time of their distribution. This method proved successful, and in all but one distribution point a return rate of over $80 \%$ was obtained. Overall, 372 (i.e. 83\%) of the 450 questionnaires were completed.

In common with all sample surveys, the results presented here are subject to margins of error. With this in mind, Table 1 provides the margins of error, for $95 \%$ confidence levels, based on the full sample size of 372. The table indicates the margin of error (plus or minus) associated with the sample size of 372 and with various percentage values. For example, a percentage value of $60 \%$ (or, of course, $40 \%$ ) has a margin of error of + or $-5.0 \%$. This indicates that the true value of the result (at the 95\% confidence interval) lies within the range 55\% and $65 \%$.

\footnotetext{
${ }^{1}$ The authors would like to express their thanks to the staff and users of the three participating library authorities.
} 
Table 1: Margins of error for 95\% confidence intervals

\begin{tabular}{|c|c|c|}
\hline Sample Size & $\begin{array}{c}\text { Percentage } \\
\text { Value }\end{array}$ & $\begin{array}{c}\text { Margin of } \\
\text { Error }\end{array}$ \\
\hline 372 & $50 / 50$ & $\pm 5.1 \%$ \\
\hline$"$ & $60 / 40$ & $\pm 5.0 \%$ \\
\hline$"$ & $70 / 30$ & $\pm 4.6 \%$ \\
\hline$"$ & $80 / 20$ & $\pm 4.1 \%$ \\
\hline$"$ & $90 / 10$ & $\pm 3.0 \%$ \\
\hline
\end{tabular}

As Table 2 illustrates, the respondents were a good and representative sample of the population as a whole, with the 15-19 age group most poorly represented, particularly for males. This is unsurprising as the questionnaires were not disseminated in specialised 'youth' libraries and teenagers, particularly males, are a notoriously poor library user group. The results are interesting in that they display a very high incidence of users between 20 and 44 and a greater proportion of male users overall.

\section{Table 2: Age and sex of respondents}

\begin{tabular}{|l|c|c|c|c|}
\hline & Males & Females & Not Specif. & Total \\
\hline Under 15 & - & 1 & - & 1 \\
\hline $15-19$ & 9 & 23 & - & 32 \\
\hline $20-29$ & 47 & 62 & - & 109 \\
\hline $30-44$ & 64 & 34 & 2 & 100 \\
\hline $45-54$ & 42 & 20 & 2 & 64 \\
\hline $55-64$ & 21 & 10 & - & 31 \\
\hline $65-74$ & 16 & 10 & 1 & 27 \\
\hline $75+$ & 3 & 3 & - & 6 \\
\hline Not specified & - & - & 2 & 2 \\
\hline Totals & $\mathbf{2 0 2}$ & $\mathbf{1 6 3}$ & $\mathbf{7}$ & $\mathbf{3 7 2}$ \\
\hline
\end{tabular}

Table 3, meanwhile, indicates the occupation of the respondents. It can be seen that the most significant category of user was that of people in paid employment or self-employed, although overall the group forms the minority (45\%). A high proportion of the users were students $(28 \%)$ or retired people (13\%). 
Table 3: Occupation of respondents

\begin{tabular}{|l|c|c|c|c|}
\hline & Male & Female & $\begin{array}{c}\text { Not } \\
\text { Specif. }\end{array}$ & Total \\
\hline In paid employment & 82 & 49 & 2 & 133 \\
\hline Self employed & 26 & 7 & 1 & 34 \\
\hline Seeking work & 21 & 7 & 1 & 29 \\
\hline Retired & 32 & 17 & 1 & 50 \\
\hline Running a home & 1 & 16 & - & 17 \\
\hline Student & 39 & 66 & - & 105 \\
\hline Not specified & 1 & 1 & 2 & 4 \\
\hline Totals & $\mathbf{2 0 2}$ & $\mathbf{1 6 3}$ & $\mathbf{7}$ & $\mathbf{3 7 2}$ \\
\hline
\end{tabular}

\section{Past efforts to obtain European information}

The questionnaire firstly asked whether the respondents had ever tried to obtain information about the European Union, and in all 103 (28\%) had actively sought European information in the past. While this was obviously a minority of the respondents, the figure was higher than those obtained in any of the three Gallup surveys of EU information needs in Britain (1993 ${ }^{\text {iii: }}$ $15 \%, 1994^{\mathrm{iv}}: 15 \%, 1995^{\mathrm{v}}$ : 18\%) commissioned by the European Commission Representation in London. This might suggest that public library users are more active and informed users of information than the general public.

In the responses to this question, there were some marked differences between the various age groups. For example, of the respondents who were under 30 years of age, $29 \%$ had previously tried to obtain EU information; while less than $13 \%$ of those respondents aged 55 or over had done so. This suggests a greater interest in European information amongst younger users. Similar differences existed in the responses from the various occupational groups. While $30 \%$ of the respondents currently in employment had previously sought EU information, only $16 \%$ of the users who were retired or running a home, and $10 \%$ of the users who were currently unemployed, had done so. The most significant user group, however, was that of students, with $36 \%$ having previously looked for European information. This reflects the importance of EU-related topics in current curricula. 
When the 103 users who had sought EU information were asked where they had gone to obtain this information, a number of very individual responses were obtained, ranging from the Department of Trade and Industry to the Internet. However, for the great majority (74) the public library had been their resource, with educational libraries (26) forming the only other significant category. Of course, as the survey was carried out in public libraries an element of bias must be acknowledged. Indeed, it is interesting to note that in a recent small street survey of 56 members of the Aberdeen public, carried out by an undergraduate student supervised by one of the authors, less than half of those respondents who had previously looked for European information had used their public library. Clearly, if unsurprisingly, current public library users view their public library as a natural source of EU information.

The 74 users who had previously looked to public libraries for obtaining EU information were then asked what types of information they had sought. As will be seen from Table 4, while employment opportunities was the most significant single category (sought by 12 users), this question received a high number of varied and highly individualistic responses, suggesting that it will be very difficult for libraries to predict the nature of information approaches that they will encounter, and implying that a wide range of information in terms of subject will be necessary within the European collection in order to fully respond to information needs. However, materials in support of business activities are likely to remain a significantly high proportion of approaches from this evidence. 


\section{Table 4: Types of EU information previously sought}

\begin{tabular}{|l|l|}
\hline Employment/job opportunities & 12 \\
\hline Market and company information & 8 \\
\hline Business opportunities & 7 \\
\hline Grants and loans & 6 \\
\hline Economic and financial issues & 5 \\
\hline Legislation & 5 \\
\hline Citizens' rights & 4 \\
\hline Travel information & 4 \\
\hline Patent information & 3 \\
\hline Political information & 3 \\
\hline Statistics & 3 \\
\hline Environmental issues & 2 \\
\hline General information on EU's activities & 2 \\
\hline Social policy & 2 \\
\hline Census information & 1 \\
\hline Current affairs in other Member States & 1 \\
\hline Customs regulations & 1 \\
\hline Energy & 1 \\
\hline Information on individual Member States & 1 \\
\hline Information on Maastricht Treaty & 1 \\
\hline Languages & 1 \\
\hline Scientific and technical research & 1 \\
\hline Trade union information & 1 \\
\hline Not specified & 5 \\
\hline &
\end{tabular}

\section{Public awareness of the Public Information Relay}

As one of the obligations of PIR members is to publicise the existence of the Relay, by using a designated logo and through various local events, the 229 respondents in Glasgow and Moray (where the service had already been made publicly available) were then asked if they were aware that their library service was part of the Relay network. In each of the two library authorities, $75 \%$ of the respondents were unaware of this fact, which suggests that at the time of the survey the promotional message had not yet fully got across to users. For the 57 respondents that were aware of the Relay service, the most effective mechanism had been by means of publicity materials and displays (identified by 22 users), although a significant proportion (14 users) did not specify the source of their awareness. 


\section{Predicted future European information needs}

The survey then went on to examine future EU information needs, and all of the respondents in the three authorities were asked to predict which topics, out of a list of 18 , they might like to find out more about. Altogether, $92 \%$ of the respondents predicted a likely future need, indicating a much higher expectation of need than had been apparent from past usage. As Table 5 indicates, although employment opportunities was again the most popular response, the users displayed a wide range of interests.

\begin{tabular}{|c|c|c|}
\hline 1. Employment/job opportunities in the EU & 161 & $43 \%$ \\
\hline 2. Citizens' rights in the EU & 141 & $38 \%$ \\
\hline $3=$ Education in the EU & 105 & $28 \%$ \\
\hline $3=$ General information on the EU's activities & 105 & $28 \%$ \\
\hline 5. EU grants and loans & 100 & $27 \%$ \\
\hline 6. EU legislation & 95 & $26 \%$ \\
\hline 7. Business opportunities in the EU & 92 & $25 \%$ \\
\hline 8. EU environmental issues & 90 & $24 \%$ \\
\hline 9. EU social policy/issues & 84 & $23 \%$ \\
\hline 10. EU economic and financial issues & 83 & $22 \%$ \\
\hline 11. Customs (duty free) regulations in the EU & 62 & $17 \%$ \\
\hline $12=$ Scientific and technical research in the EU & 55 & $15 \%$ \\
\hline $12=$ Transport in the EU & 55 & $15 \%$ \\
\hline 14. EU statistics & 53 & $14 \%$ \\
\hline 15. Farming, forestry and fishing in the EU & 51 & $14 \%$ \\
\hline 16. EU market and company information & 48 & $13 \%$ \\
\hline 17. European patents and standards & 35 & $9 \%$ \\
\hline 18. Energy in the EU & 27 & $7 \%$ \\
\hline
\end{tabular}

A number of other categories were also identified by individual users. These included: competition policy in the EU; the implications of an independent Scotland in Europe; languages; and travel information.

Again, on examining the responses to this question from the various age groups, some noticeable (and perhaps unsurprising) variances can be found. For example, amongst those users under 30 years of age and those aged 30-54, employment opportunities was the most frequently predicted topic (58\% and $42 \%$ of respondents, respectively); while amongst those users aged 55 and above, a need for information on job opportunities was identified by just $13 \%$. Instead, the older users regarded citizens' rights (48\%) as the topic on which they would most likely require information. It was particularly interesting to note that just $5 \%$ of the users aged under 30 expressed no interest in any of the topics listed. This compares with $19 \%$ of the users aged 55 and above, and bears out the Gallup polls' findings that there is a 
particular interest in being better informed about Europe amongst Britain's young adults (i.e. those aged 16-24, according to the Gallup definition).

Some occupational differences, too, can be identified. While employment opportunities was the most frequently identified topic by students (59\%), jobseekers (52\%) and those in paid employment (44\%), self-employed respondents clearly felt other topics might be more relevant to their needs and ranked job opportunities third (at 35\%) behind business opportunities (53\%) and EU grants and loans (41\%). Meanwhile, those respondents who were retired or were running a home felt that citizens' rights (45\%) would potentially be the most useful topic. With regard to overall interest in European information, the level appeared to be lowest amongst the retired, with $22 \%$ expressing no interest in any of the topics listed. This compares with $12 \%$ of those respondents running a home, $10 \%$ of those seeking work, $9 \%$ of those self-employed, $7 \%$ of those in paid employment, and just $3 \%$ of the students.

In general, the responses to this question were remarkably similar in all three library authorities, with employment opportunities and citizens' rights rating highly in all cases. There were, however, one or two differences worthy of note, particularly between respondents in Glasgow and Moray. For example, while 33\% (i.e. 'ranked' in 2nd place) of the users in Glasgow predicted business opportunities in the EU would be a potentially useful topic, only $15 \%$ (i.e. 'ranked' 11th) of Moray library users felt that this would be the case. In contrast, $25 \%$ (i.e. 'ranked' 7 th) of the library users in the predominantly rural area served by Moray libraries felt that EU farming, forestry and fishing information would be valuable; while, unsurprisingly, only 7\% (i.e. 'ranked' 18th) of respondents in the urban area of Glasgow expressed an interest in such topics. In each of these cases, the responses from Aberdeen library users lay roughly midway (i.e. $23 \%$ and $13 \%$, respectively) between the two extremes.

While the overall figures displayed in Table 5 are relatively high, it is interesting to note that they are still decidedly lower than any of those gathered as part of the Gallup polls where, in 1995 for example, members of the general public predicted a future need for information about: what the EU is doing in their region (73\%); employment opportunities (72\%); the environment (69\%); working conditions, and health and safety regulations (69\%); equal opportunities (68\%); education and languages (66\%); professional standards and qualifications (63\%); travel and customs duties (55\%); and going to live in another EU country $(53 \%)$. These are intriguing variances, particularly where direct comparisons can be 
made, such as in employment opportunities and environmental information, and perhaps suggest that the different methods of data collection employed (the Gallup polls comprised face-to-face interviews with members of the public) was a highly influential factor.

Interestingly, the responses indicated in Table 5 also appear to contradict the PIR members' impressions of library users' EU information needs, which were obtained by means of a separate questionnaire-based survey as part of the British Library project. Given a list of 18 subjects identical to that appearing in the user survey questionnaire, the libraries indicated that the most frequently requested topics (i.e. asked for on at least a weekly basis in at least $30 \%$ of the responding authorities) were: (1) Statistics; (2) General information on the EU's activities; (3) Market and company information; (4) Grants and loans; (5) Business opportunities; and (6) Legislation. Therefore, while the libraries reported a high level of use of statistical and business-related information that might be used in a professional or commercial capacity, the library users' responses of employment, citizens' rights and educational information suggest more of an emphasis on the individual and on the private citizen.

\section{Predicted reasons for wanting to obtain EU information}

Finally, those users who indicated that they might want to obtain EU information in the future were asked why they might want the information, and the responses are summarised in Table 6. Additional reasons identified by individual respondents were 'religious reasons' and 'environmental activism and lobbying'.

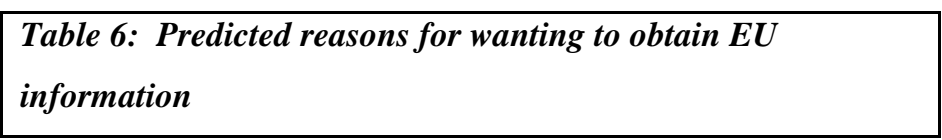

\begin{tabular}{|l|c|c|}
\hline Educational/study reasons & 168 & $49 \%$ \\
\hline A general interest & 147 & $43 \%$ \\
\hline Work reasons & 139 & $41 \%$ \\
\hline Job-seeking reasons & 113 & $33 \%$ \\
\hline Recreational reasons & 55 & $16 \%$ \\
\hline
\end{tabular}

Again there were some unsurprising differences in the responses of the various age and occupational groups. Those respondents aged under 30 , and more specifically those that were students, identified educational reasons (80\%) and job seeking reasons (53\%) as the 
most likely motives for seeking EU information; while respondents aged 30-54, particularly those currently in employment, felt a need would most probably arise because of workrelated reasons (56\%). Those respondents currently seeking work, meanwhile, believed that work-related reasons (62\%) and jobseeking reasons (54\%) would be their prime motives; while the retired respondents and those running a home indicated that they would most probably require EU information simply because of a general interest (85\% and $47 \%$, respectively).

\section{Conclusions}

To summarise, this user survey found that $28 \%$ of users had attempted to obtain European information in the past, and that $72 \%$ of these (i.e. $20 \%$ of all of the users surveyed) had used their public library to find the information sought. $92 \%$ of users predicted a likely future need for European information and displayed a wide range of subject interests. The findings would also support those of Gallup, that there is a particular interest in being well informed about Europe amongst young people, primarily in response to more Europe-aware educational curricula or in broadening job opportunities. These are all positive results which show a growing actual and predicted level of need for European information, and indicate, amongst public library users at least, an increasing awareness of the potential significance of EU information - facts which would appear to bode well for the future of the PIR. However, the user survey also demonstrates the significance to public library users of European information for educational (49\%), business related (41\%) and employment (33\%) reasons. None of these are seen as lying within the remit of the Public Information Relay, which focuses rather on the provision of 'general citizen' information (sought by $43 \%$ of survey respondents). It was only amongst those respondents that were retired or running a home that citizens' rights information was the type of information that respondents predicted most likely to be sought in the future. The findings support the continuing wider view of the public library service in support of a range of economic, educational and social activities on the part of users, in all of which there are likely to be demands for materials providing a European perspective.

\section{References}

i Marcella, Rita, Baxter, Graeme, and Parker, Susan. European Union information in public libraries in the United Kingdom. London: British Library, 1996 [British Library Research 
and Innovation Report no. 19]. Available from the British Thesis Service, British Library Document Supply Centre, Boston Spa, Wetherby, West Yorkshire, LS23 7BQ.

ii Marcella, Rita, Baxter, Graeme, and Parker, Susan. The provision of European information by public libraries in the UK: results of a British Library Research and Innovation Centre funded research project. Library Management, 18(1), 1997, pp.7-41.

iii European Commission. Information deficit highlighted by EC survey. [Press Release] London: European Commission, 10 November 1993.

iv European Commission. Increased call for information in EU survey. [Press Release] London: European Commission, 10 November 1994.

v European Commission. Britain's youth pro-European and becoming more so. [Press Release] London: European Commission, 9 November 1995. 


\section{EUROPEAN UNION INFORMATION IN PUBLIC LIBRARIES}

As part of a project funded by the British Library, the Robert Gordon University in Aberdeen is currently investigating the provision of European information in public libraries. It would be appreciated if you could spare a few moments to answer the following questions.

1. Have you ever tried to obtain information about the European Union?

YES... $\quad$ NO...

If YES, where did you go to obtain this information? (Please provide details)

2. Have you ever tried to obtain European information from a public library?

YES $\square \quad$ NO $\square$

If YES, what kind of information did you try to obtain? (Please provide details)

3. Are you aware that Glasgow City Libraries is part of a network of public libraries providing European information?

YES $\square \quad$ NO

If YES, how did you find this out? (Please provide details)

4. Which of the following subjects do you feel you might want to find out more about, either at the present or in the future? (Please tick all relevant boxes)

General information on the EU's activities Customs (duty free) regulations in the EU Employment/job opportunities in the EU Education in the EU

EU legislation

EU social policy/issues

Citizens' rights in the EU

Transport in the EU

Energy in the EU

EU environmental issues

Farming, forestry and fishing in the EU
EU economic and financial issues

Business opportunities in the EU

EU market and company information

EU grants and loans

Scientific and technical research in the EU

European patents and standards

EU statistics

Other (please specify) 
5. For what reasons might you want this information? (Please tick all relevant boxes)

Educational/study reasons

Work reasons

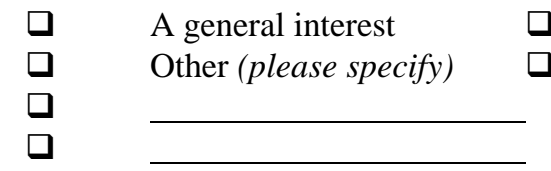

Job-seeking reasons

Recreational reasons

6. Why are you visiting the library today? (Please tick all relevant boxes)

To borrow/return books

To borrow/return cassettes/CDs/videos

$\begin{array}{ll}\square & \text { To see an exhibition/event } \\ \square & \text { To browse } \\ \square & \text { Other, (please specify) } \\ \square & \\ \square & \\ \square & \end{array}$

7. Please provide some details about yourself:
(a) Are you:
Male
Female
(b) Are you:
Under 15 years of age
$15-19$
20-29
$30-44$
55-64
$65-74$
$\square \quad 75$ or over
(c) Are you:
In paid employment
$\square \quad$ Retired
Self employed
Seeking work
$\square \quad$ Running a home
口 Student

If in paid employment or self employed, please specify your occupation:-

Thank you very much for your cooperation

Please return this form to the issue/enquiry desk 